\title{
1 Expansion of corals on temperate reefs: direct and indirect effects of
}

\section{2 marine heatwaves}

3

4 Tuckett $\mathrm{CA}^{1 *}$, de Bettignies $\mathrm{T}^{1,2}$, Fromont $\mathrm{J}^{3}$ and Wernberg $\mathrm{T}^{1}$

5

$6 \quad{ }^{1}$ School of Biological Sciences and UWA Oceans Institute, The University of Western

7 Australia, Cnr Fairway and Service Rd 4, Crawley WA 6009, Australia

$8 \quad{ }^{2}$ UMS 2006 Patrimoine Naturel, Muséum National d'Histoire Naturelle, 36 rue Geoffroy

9 Saint-Hilaire, 75005 Paris, France

$10{ }^{3}$ Western Australian Museum, Locked Bag 49, Welshpool DC, WA 6986, Australia

11

$12 *$ Corresponding author: chenae.tuckett@research.uwa.edu.au

13

14 Keywords: Tropicalisation, Kelp forests, Seaweed decline, High-latitude corals, Plesiastrea 15 versipora, 


\section{Abstract}

17 Globally, many temperate marine communities have experienced significant temperature increases over recent decades in the form of gradual warming and heatwaves. As a result, these communities are shifting towards increasingly subtropical and tropical species compositions. Expanding coral populations have been reported from several temperate reef ecosystems along warming coastlines; these changes have been attributed to direct effects of gradual warming over decades. In contrast, increases in coral populations following shorterterm extreme warming events have rarely been documented. In this study, we compared coral

24 populations on 17 temperate reefs in Western Australia before (2005/06) and after (2013) multiple marine heatwaves (2010-2012) affected the entire coastline. We hypothesised that coral communities would expand and change as a consequence of increasing local populations and recruitment of warm-affinity species. We found differences in coral community structure over time, driven primarily by a four-fold increase of one local species, Plesiastrea versipora, rather than recruitment of warm-affinity species. Coral populations became strongly dominated by small size classes, indicative of recent increased recruitment or recruit survival. These changes were likely facilitated by competitive release of corals from dominant temperate seaweeds, which perished during the heatwaves, rather than driven by direct temperature effects. Overall, as corals are inherently warm-water taxa not commonly associated with seaweed-dominated temperate reefs, these findings are consistent with a net tropicalisation. Our study draws attention to processes other than gradual warming that also influence the trajectory of temperate reefs in a changing ocean.

\section{Introduction}


Temperature is a major driver of the biogeography of species across Earth's biomes

40

41

42

and through time. By limiting or enhancing physiological processes and influencing ecological interactions, temperature produces consistent patterns in the distribution and abundance of species. Within the world's oceans these patterns largely follow temperature gradients associated with latitude and depth (Gaston 2000; Tittensor et al. 2010; Wernberg et al. 2013b). Consequently, with the oceans warming on average at rates of $\sim 1.5^{\circ} \mathrm{C} 100 \mathrm{yr}^{-1}$ or more in global hotspots (Hobday and Pecl 2013), changes in species distributions and abundances are increasingly being documented (Perry et al. 2005; Last et al. 2011; Wernberg et al. 2011; Poloczanska et al. 2013). One particularly prevalent change is the poleward shift of subtropical and tropical species, and the subsequent 'tropicalisation' of temperate reefs (Nakamura et al. 2013; Vergés et al. 2014b; Richards et al. 2016; Wernberg et al. 2016b). Temperate reefs are usually characterised by dense stands of seaweeds that support diverse communities of high social and economic value (Schiel and Foster 1986; Steneck and Johnson 2013; Bennett et al. 2016). However, a decline in cool-water seaweeds and an influx of subtropical and tropical organisms is occurring on many high-latitude reefs. While some tropical species of coral, fish, seaweeds and invertebrates have always been present at high latitudes, recent increases in their diversity and abundance have shifted community structure (Nakamura et al. 2013; Wernberg et al. 2013a, 2016a; Vergés et al. 2014a; Richards et al. 2016) with the resulting tropicalisation being most distinct where the dominant benthos has changed towards a distinctive tropical fauna such as corals (e.g., Mezaki and Kubota 2012; Vergés et al. 2014b).

Expansion of coral populations has largely occurred in association with gradual temperature increases over decadal time scales. One of the most striking examples comes 
62

from Japan $\left(32.75^{\circ} \mathrm{N}\right)$ where some reefs were once populated by temperate seaweeds, but are now Acropora-dominated coral communities (Yamano et al. 2011; Yara et al. 2011; Mezaki and Kubota 2012, Denis et al. 2013). Similarly, in South Korea $\left(33.41^{\circ} \mathrm{N}\right)$ recent high recruitment rates and negatively skewed size-frequency distributions suggest that local coral populations are increasing (Denis et al. 2014; Vieira et al. 2016). Populations of Acropora spp. in North America and the introduced species Oculina patagonica in the Mediterranean Sea have also expanded poleward in response to gradual warming (Precht and Aronson 2004; Serrano et al. 2013). Likewise, in the southern hemisphere, some corals have undergone poleward range extensions in both eastern and western Australia, increasing the diversity and abundance of corals at temperate latitudes (Thomson 2010; Baird et al. 2012; Richards et al. 2016). Such responses to recent warming are consistent with historical fluctuations in coral distributions with periods of cooling and warming (Precht and Aronson 2004; Greenstein and Pandolfi 2008). Thus, gradual warming seems to enable population expansions of these characteristically tropical fauna into temperate communities.

In contrast to gradual warming, discrete spikes in temperature appear to have negative effects on corals at high latitudes. For example, in 2010 , Lord Howe Island $\left(\sim 31^{\circ} \mathrm{S}\right)$ on the east coast of Australia experienced a heatwave of multiple degree heating weeks, resulting in significant bleaching of the southern-most coral reef in the world (Harrison et al. 2011). Similarly, a 2011 marine heatwave in the southeast Indian Ocean impacted coral communities along the Western Australian coastline with 10-60\% coral bleaching between 32 and $28^{\circ} \mathrm{S}$ (Pearce et al. 2011; Abdo et al. 2012; Moore et al. 2012; Smale and Wernberg 2012; Lafratta et al. 2016). The high-latitude endemic coral, Coscinaraea marshae, also underwent severe bleaching of $95 \%$ of colonies in deep waters near Rottnest Island $\left(\sim 32^{\circ} \mathrm{S}\right)$ 
during the 2011 marine heatwave, and at the same latitude reduced coral calcification rates were attributed to the heatwave (Thomson et al. 2011; Foster et al. 2014). In 2003 a

Mediterranean heatwave saw partial and complete tissue necrosis and mortality in two endemic coral species (Garrabou et al. 2009; Kersting et al. 2013). However, all these studies focused on immediate, directly adverse responses (bleaching, tissue necrosis and mortality) to discrete warming, and did not consider longer-term effects of changes in demographic processes or ecological interactions.

The indirect effects of ecological interactions mediated by temperature, such as competition with cool-water seaweeds, are also likely to shift after a thermal event. Seaweeds dominate temperate reefs (Steneck and Johnson 2013), where they likely contribute to suppressing coral populations through physical interference (e.g. shading and abrasion) and superior resource utilisation (e.g. light and space) (Coyer et al. 1993; Miller and Hay 1996; Thomson et al. 2012). Temperate seaweeds are vulnerable to marine heatwaves which can lead to a decline in performance and abundance (e.g. Serrano et al. 2012; Vergés et al. 2014b; Wernberg et al. 2016a). Declines in seaweed cover are likely to alleviate competitive stress on coral communities through reduced physical interference and increased resource availability, potentially increasing successful recruitment and recruit survival. This, in turn, provides an opportunity for coral populations to expand through local population increase and recruitment of new species, especially when the seaweeds cannot recover, for example due to increases in herbivores (Bennett et al. 2015).

Coral establishment and growth is a slow process, and it takes time for changes in recruitment and recruit survival to manifest in visibly expanding populations. Early recruits are microscopic in size and the slow growth rate of corals, particularly at high latitudes (e.g. 
108 Lough and Barnes 2000; Carricart-Ganivet 2004; Rodolfo-Metalpa et al. 2006; Burgess et al.

109 2009), implies detection is only possible months after initial recruitment. Consequently,

110 community responses to discrete events cannot be inferred from immediate responses such as

111 mortality alone, but need to also consider demographic processes and indirect ecological

112 effects which play out over relatively long time scales.

113 Here we investigate changes in coral populations on temperate reefs along the mid-

114 west coast of Australia (29-30 $\mathrm{S})$. Coral surveys completed in 2005 and 2006 by the Western

115 Australian Museum (WAM) (Fromont et al. 2006) were repeated in 2013. Within this period

116 the mid-west region experienced significant warming where, between 2010 and 2012,

117 consecutive hot summers were characterised by severe marine heatwaves (Hobday et al.

118 2016; Pearce and Feng 2013). In the aftermath of these heatwaves, temperate communities

119 collapsed at their northern (warm) margin and canopy-forming seaweeds declined by $40 \%$ in

120 the mid-west (Pearce et al. 2011; Smale and Wernberg 2013; Wernberg et al. 2013a, 2016a).

121 Although the heatwaves resulted in coral stress and bleaching (Pearce et al. 2011; Thomson

122 et al. 2011; Abdo et al. 2012; Moore et al. 2012; Smale and Wernberg 2012; Foster et al.

123 2014), the decline in temperate seaweeds could have provided increased habitat availability

124 and new ecological niches for corals on mid-west reefs. As a result, we hypothesised that

125 coral communities would have expanded from local population increases and range shifts of

126 warm-affinity species.

127

128 Methods

129 Study area 

zone of temperate and tropical biota (Fromont et al. 2006; Wernberg et al. 2013a). Study sites

132 (reefs) were nested within four regions: Dongara $\left(29^{\circ} 016 ' \mathrm{~S}, 114^{\circ} 055^{\prime} \mathrm{E}\right)(3$ sites $)$; Green Head $133\left(30^{\circ} 004^{\prime} \mathrm{S}, 114^{\circ} 058^{\prime} \mathrm{E}\right)(3$ sites $)$; Jurien Bay $\left(30^{\circ} 018^{\prime} \mathrm{S}, 115^{\circ} 002^{\prime} \mathrm{E}\right)(6$ sites); and Cervantes $134\left(30^{\circ} 030^{\prime} \mathrm{S}, 115^{\circ} 004^{\prime} \mathrm{E}\right)(5$ sites $)$ (Fig. 1).

\section{Coral surveys}

This study contrasted two datasets collected $\sim 8$ years apart at the same sites using identical methods. The first data set was collected in 2005/2006 (before heatwaves) and the second one in 2013 (after heatwaves). The 'before heatwaves' data were collected as part of a comprehensive biodiversity study of multiple habitat types by the WAM and the Australian

141 Commonwealth Scientific and Industrial Research Organisation (CSIRO) (Fromont et al.

142 2006). Of the initial 30 sites surveyed by WAM, 17 sites were re-sampled in 2013 and used

143 in this comparison. The sites were selected based on the presence of habitats conducive for

144 coral presence (rocky reefs) or habitats where corals were previously found. The 17 sites

145 encompassed a variety of environmental conditions with different distances from the shore

146 (inshore, midshore, offshore) and wave exposure (sheltered, exposed) within each region

147 (Dongara, Green Head, Jurien Bay and Cervantes) (Electronic supplementary material, ESM

148 Table S1). At each site, all corals $>1 \mathrm{~cm}$ diameter (corresponding to an area of $1.6-4.6 \mathrm{~cm}^{2}$ )

149 were counted, identified and measured within three haphazardly placed $5-\mathrm{m}^{2}(1 \times 5 \mathrm{~m})$

150 transects by divers using SCUBA. Transects were five contiguous $1-\mathrm{m}^{2}$ quadrats placed at

151 least $10 \mathrm{~m}$ apart within $20-30 \mathrm{~m}$ of the site marker. Approximately $10-15 \mathrm{~min}$ were spent

152 searching for corals in each transect. The haphazard placement of transects in both before and 
after surveys ensured transects included rocky reef habitat and incorporated representative sampling across seaweed types where seaweeds were a significant constituent of the reefscape (e.g. areas of Ecklonia radiata, Sargassum spp. or turfs; see ESM Table S1 for list of dominant seaweeds at each site). Areas visibly dominated by corals were not targeted specifically. All coral colonies were photographed with a scale to assist with species identifications and to allow subsequent size measurements. Species identity was assigned based on morphological features following Veron and Marsh (1988) and Veron (1993, 2000).

\section{Colony counts and species presence}

Species of the genus Montipora were pooled to genus as species identity could not be confidently assigned from photographs (distinguishing features can be $<1 \mathrm{~mm}$ ). All other corals were identified to species.

Colony counts were used as a measure of abundance of each species. Due to a high proportion of zeros at the transect level, abundances were pooled (summed) for each site. Site counts were then transformed $(\log x+1)$ to down-weigh very abundant taxa and allow representation of patterns within the whole coral community (Anderson et al. 2008).

Transformed site counts were then used as replicates to test for differences in coral communities with permutational analysis of variance (PERMANOVA) between years (fixed) and regions (fixed). The PERMANOVA test was based on a zero-adjusted Bray-Curtis similarity matrix and followed by pairwise tests when significance $(P<0.05)$ was met (Anderson et al. 2008). Differences in the multivariate structure of the coral communities between sampling times and among regions were visualised with a principal coordinates ordination based on the same matrix used for PERMANOVA. Non-parametric Spearman 
rank correlations $(>0.7)$ overlaid the ordination plot to show coral species likely contributing most to dissimilarities. The contribution of species to differences between years was also investigated with a similarity percentage (SIMPER) analysis on transformed $(\log x+1)$ site counts.

\section{Demographic measurements}

Most high-latitude corals have flat, encrusting or laminar forms (Sommer et al. 2014), and many of the corals encountered were small individuals with minimal thickening of skeletal structures. Consequently, area was considered a good proxy for age and performance, and was estimated for each colony based on measurements of minimum and maximum diameter and the formula for an ellipse (area $=\pi \times r_{\min } \times r_{\max }$, where $r$ is the radius). Size frequencies were constructed from pooled area measurements per species for before and after periods. The number of bins used in the frequency distributions was based on the rounded result from Sturges' formula $(1+3.322 \log [\mathrm{N}]$, where $\mathrm{N}$ is the sample size $)$, effective for sample sizes <200 (Sturges 1926). Bin size was then calculated from the range (minus outliers) divided by the number of bins. A two-sample Kolmogorov-Smirnov test was used to determine whether size frequencies were significantly different between pooled before and after data, and a two-sample t-test was used to test whether the mean number of small (1.6$\left.11.8 \mathrm{~cm}^{2}\right)$ and large $\left(12.4-27.5 \mathrm{~cm}^{2}\right)$ colonies differed between times.

\section{Results}



before the heatwaves to eleven after the heatwaves. Also, the total number of coral colonies recorded increased more than two-fold (76 before, 163 after) across the 17 sites, with the 200 increase largely being corals smaller than $12 \mathrm{~cm}^{2}$ (Table 1; ESM Table S2). Of the 17 sites 201 re-surveyed in 2013, three sites had new coral species not recorded in the surveys before the heatwaves. PERMANOVA confirmed that these increases constituted a significant change in multivariate community structure between the before and after surveys (Table 1; Fig. 2).

There were also significant differences between regions but the pairwise comparisons did not reveal any systematic latitudinal differences between regions (Table 1; Fig. 2). Separation of sampling times in the midwest regions was predominantly along PCO1, which was highly correlated with changes in Plesiastrea versipora. Changes in Coelastrea aspera, Pocillopora damicornis and species of Montipora were strongly associated with both PCO1 and PCO2. Specifically within the regions of Dongara and Cervantes time differences showed alignment with changes in Turbinaria mesenterina and P. damicornis. At Green Head changes over

211 time showed association with PCO2 and with changes in Montipora species. There were few colonies $(<40)$ of all species except $P$. versipora, even in pooled samples. Thus, size frequencies were only constructed for P. versipora; even within this species the sample size for Dongara ( $N=5$ colonies) was limiting and thus this region was not included in this analysis. The size-frequency distributions were significantly different

216 before and after the heatwaves (two-sample Kolmogorov-Smirnov test, $P<0.05$ ). After the 217 heatwaves size distributions where clearly negatively skewed due to an increase in the smaller size classes, with $70 \%$ of all colonies sampled in 2013 smaller than $12 \mathrm{~cm}^{2}$ (Fig. 3). 
219 In contrast, $63 \%$ of all $P$. versipora colonies sampled before the heatwaves were larger than $12 \mathrm{~cm}^{2}$.

The species with the greatest change in mean abundance over time was, by far, $P$.

222 versipora (Fig. 4; ESM Table S2). Smaller P. versipora colonies $\left(<12 \mathrm{~cm}^{2}\right)$ from Green

223 Head, Jurien Bay and Cervantes increased significantly from a mean of $2.5( \pm 1.7 \mathrm{SD})$

224 colonies before the heatwaves to a mean of $25( \pm 8.7)$ colonies after the heatwaves (twosample t-test, $P<0.05)$. The mean number of larger colonies $\left(>12 \mathrm{~cm}^{2}\right)$ did not increase from before $(3.0 \pm 2.6)$ to after $(6.0 \pm 3.0)$ the heatwaves (two-sample t-test, $P>0.05)$. Coral species of warmer affinity increased but this was limited to one Acropora millepora and six Alveopora fenestrata colonies; this increase did not affect the overall community changes between datasets.

\section{Discussion}

In this study, we found significant increases in coral abundances on temperate reefs over an $\sim 8$-yr period associated with gradual warming and heatwaves. This change was driven by increases in species common to both sampling periods. New, more tropically affiliated species were recorded but in very low abundances insufficient to drive a shift in the community structure relative to the substantial increase in other species. The most pronounced abundance change was found for $P$. versipora. The strongly skewed sizefrequency distributions of $P$. versipora colonies demonstrated a large increase in small colonies, suggesting an increase in recruitment or recruit survival after the heatwaves. Age estimates for small $P$. versipora colonies $\left(<12 \mathrm{~cm}^{2}\right)$ reinforce the idea of recent juvenile 
241 success. Based on a conservative growth rate of $4 \mathrm{~mm} \mathrm{yr}^{-1}$ (average rate calculated from

242 South Australia, where water temperatures were cooler than the mid-west; Burgess et al.

2432009 ) the age of small colonies recorded after the heatwave could be 1.3 to $7.3 \mathrm{yr}$ (radius

244 range of colonies $<12 \mathrm{~cm}^{2}$ colonies was $\sim 0.5-2.9 \mathrm{~cm}$ ). The magnitude of this population

245 expansion indicates that our findings are not due to sampling artefacts and the increase seen

246 here is unlikely due to cyclical variation as size-frequency distributions were clearly

247 unimodal and negatively skewed in 2013. If this was a cyclical change, we would expect to

248 see a multimodal distribution of progressive cohorts but this was not the case. Overall, these

249 results are consistent with our hypotheses, indicating that there has been a change in coral

250 communities driven by substantial local population expansion and, to a lesser extent, a

251 possible increase in warm-affinity species (see below).

Extreme temperatures during the marine heatwaves are unlikely to have directly driven the observed changes in coral communities and the success of recruitment or survival of small $P$. versipora. Coral larvae and microscopic recruits are heat sensitive, with temperature stress prompting reduced pre-competency periods, increased mortality during metamorphosis, and increased mortality post settlement (Edmunds et al. 2001; Bassim and Sammarco 2003; Nozawa and Harrison 2007; Randall and Szmant 2009; Yakovleva et al. 2009; Ross et al. 2013). While negative effects do not always result from heat stress (e.g. Edmunds et al. 2001), it is likely the long duration and high intensity of the 2011 heatwave would have had deleterious effects on reproduction and early life stages. Specifically, coral

261 recruitment (likely due to reduced reproductive output) at the Houtman Abrolhos Islands (approximately $70 \mathrm{~km}$ northwest of the study region) in 2011 and 2012 was significantly reduced compared to subsequent cooler years, (Markey et al. 2016). Further, adult coral 
colonies, which are generally more resilient to temperature stress than early life stages (larvae

265

266

267

268

269

270

271

272

273

274

275

276

277

278

279

280

281

282

283

284

285

286 and microscopic recruits), experienced bleaching and reduced growth during the heatwave periods (Pearce et al. 2011; Thomson et al. 2011; Abdo et al. 2012; Moore et al. 2012; Smale and Wernberg 2012; Foster et al. 2014). Thus, direct effects of high temperature during the heatwaves would most likely have had a net negative effect on the mid-west coral communities and would not have benefitted the juvenile coral population.

The recent success of small (juvenile) corals is likely the consequence of competitive release mediated by temperature through the reduction in canopy-forming temperate seaweeds and increases in herbivorous fishes. Seaweeds often limit corals in temperate environments through competitive stress, abrasion and dislodgement (Miller and Hay 1996). Seaweed removal experiments and natural canopy-free patches have shown a relaxation of these processes, leading to greater coral persistence, increased recruitment success and growth (Coyer et al. 1993; Miller and Hay 1996; Thomson et al. 2012). The heatwaves caused a substantial loss of seaweed canopy cover, which declined from $80-90 \%$ to $50 \%$ or less across the study region (Fig. 5a, b) (Smale and Wernberg 2013; Wernberg et al. 2013a, 2016b), a loss that has been maintained and reinforced over time by increasing herbivory by tropical fishes (Bennett et al. 2015). The loss of seaweed canopies would have facilitated the growth and survival of juvenile corals that recruited prior to the heatwave (Fig. 5c-e), presumably outweighing the direct negative effects of the heatwave on these animals. This could explain why high frequencies were found across several small size classes for $P$. versipora rather than within a single size class (which would have suggested a single recruitment pulse). We expect this recruitment facilitation to continue where the heatwave has caused a persistent shift to low canopy abundance (Wernberg et al. 2016b). 
and were found in abundances too low for size-frequency analyses. In some instances, species recorded before the heatwave did not increase or were not recorded after the heatwave. It remains unclear why other local species did not show stronger positive responses to the direct and indirect effects of the heatwaves. Lower initial abundances compared to $P$. versipora could have limited propagule supply such that abundance changes would take longer to manifest, especially if these species also have less opportunistic life histories.

Similarly, the increase in new warm-water species was very small. Warm-water, low-latitude species could have been limited by their lower environmental tolerances, not only to temperature but also depth, water clarity and light levels (Sommer et al. 2014; Keith et al. 2015; Mizerek et al. 2016).

Dispersal and recruitment could also be a factor limiting the response of warm-water species in this study. Long-distance dispersal from upstream sources would be required for an increase in warm-water species as the nearest coral reefs are $\sim 70 \mathrm{~km}$ offshore at the Houtman

301 Abrolhos Islands $\left(28^{\circ} \mathrm{S}\right)$. Under normal conditions, larval longevity could favour connectivity

302 between the Houtman Abrolhos Islands and the mid-west as after $\sim 100 \mathrm{~d}$ (the last stage of coral mortality) patterns show increasing mortality (Graham et al. 2008; Markey et al. 2016).

304 However, coral larvae show reduced pre-competency periods under thermal stress, which could promote settlement on natal reefs and reduce dispersal duration within the pelagic

306 period (Nozawa and Harrison 2000; Heyward and Negri 2010). In addition, the timing of

307 arrival of new warm-water species relative to the loss of seaweed canopies might have

308 limited successful settlement and recruitment. Thus, the probability of successful dispersal to the coastal reefs in the study area seems very low, and the likelihood of recruit limitation 
high. Thermal stress to early life stages during the heatwaves and dispersal limitation may be at least partially responsible for warm-water species not increasing.

The species predominantly responsible for the increase in coral abundance, $P$. versipora, is often considered a temperate species. However, it has been recorded in many

314 more tropical than temperate locations ( $\sim 80 \%$ of 283 records north of $30.3^{\circ} \mathrm{S}$; Atlas of Living

315 Australia, www.ala.org.au) and is perhaps more correctly classified as a tropical species with broad environmental tolerances. As temperate reefs are generally characterised by abundant seaweeds and not corals, the substantial expansion of coral populations observed in this study is consistent with the ongoing tropicalisation of temperate reefs seen in Western Australia and globally (Yamano et al. 2011; Wernberg et al. 2013a, 2016a; Vergés et al. 2014b). It is likely that greater juvenile recruitment and/or survival of newly recruited corals was largely the indirect result of competitive release from seaweeds rather than a response to consecutive marine heatwaves. However further investigation is needed to determine whether coral increases will be moderated by changing community interactions, such as the increase in turf

324 algae (Wernberg et al. 2013a, 2016a) and herbivory (Bennett et al. 2015). Regardless, we expect to see coral populations increase in these high-latitude reef communities with future warming, heatwaves and seaweed declines.

\section{Acknowledgements}

329 This study was funded by grants to TW from the Australian Research Council

330 (FT110100174) and the Herman Slade Foundation (HSF13-13). The initial surveys were 331 supported by the Western Australian Museum, the CSIRO and the Strategic Research Fund 
for the Marine Environment. We thank Florian de Bettignies for providing a detailed map of

333

334

335

336

337

338

339

340

341

342

343

344

345

346

347

348

349

350

351

352

353

354

355

356

357

358

359

360

361

362

363

364

365

366

367

368

369

370

the study region (Fig. 1). Three anonymous reviewers assisted in refining earlier drafts. The

authors have no conflicts of interest to declare.

\section{References}

Abdo DA, Bellchambers LM, Evans SN (2012) Turning up the heat: increasing temperature and coral bleaching at the high latitude coral reefs of the Houtman Abrolhos Islands. PLoS One 7:e43878

Anderson MJ, Gorley RN, Clarke KR (2008) PERMANOVA for PRIMER: guide to software and statistical methods. PRIMER-E Ltd., Plymouth, United Kingdom

Baird AH, Sommer B, Madin JS (2012) Pole-ward range expansion of Acropora spp. along the east coast of Australia. Coral Reefs 31:1063-1063

Bassim KM, Sammarco PW (2003) Effects of temperature and ammonium on larval development and survivorship in a scleractinian coral (Diplora strigosa). Mar Biol 142:241-252

Bennett S, Wernberg T, Harvey ES, Santana-Garcon J, Saunders BJ (2015) Tropical herbivores provide resilience to a climate-mediated phase shift on temperate reefs. Ecol Lett 18:714-723

Bennett S, Wernberg T, Connell SD, Hobday AJ, Johnson CR, Poloczanska ES (2016) The 'Great Southern Reef': social, ecological and economic value of Australia's neglected kelp forests. Mar Freshw Res 67:47-56

Burgess SN, McCulloch MT, Mortimer GE, Ward TM (2009) Structure and growth rates of the high-latitude coral Plesiastrea versipora. Coral Reefs 28:1005-1015

Carricart-Ganivet JP (2004) Sea surface temperature and the growth of the west Atlantic reefbuilding coral Montastraea annularis. J Exp Mar Bio Ecol 302:249-260

Coyer JA, Ambrose RF, Engle JM, Carroll JC (1993) Interactions between corals and algae on a temperate zone rocky reef: mediation by sea urchins. J Exp Mar Bio Ecol $167: 21-37$

Denis V, Mezaki T, Tanaka K, Kuo CY, De Palmas S, Keshavmurthy S, Chen CA (2013) Coverage, diversity, and functionality of a high-latitude coral community (Tatsukushi, Shikoku Island, Japan). PLoS One 8:e54330

Denis V, Ribas-Deulofeu L, Loubeyres M, De Palmas S, Hwang S-J, Woo S, Song J-I, Chen CA (2014) Recruitment of the subtropical coral Alveopora japonica in the temperate waters of Jeju Island, South Korea. Bull Mar Sci 91:85-96

Edmunds PJ, Gates RD, Gleason DF (2001) The biology of larvae from the reef coral Porites asteroides and their response to temperature disturbances. Mar Biol 139:981-989

Foster T, Short JA, Falter JL, Ross C, McCulloch MT (2014) Reduced calcification in Western Australian corals during anomalously high summer water temperatures. J Exp Mar Bio Ecol 461:133-143 
Fromont J, Hass C, Marsh L, Moore G, Salotti M, Titelius M, Whisson C (2006) Biodiversity of marine fauna on the Central West Coast, SRFME Final Milestone Report December 2006. Western Australian Museum, Perth, Western Australia, 86 pp

Garrabou J, Coma R, Bensoussan N, Bally M, Chevaldonné P, Cigliano M, Diaz D, Harmelin JG, Gambi MC, Kersting DK, Ledoux JB, Lejeusne C, Linares C, Marschal C, Pérez T, Ribes M, Romano JC, Serrano E, Teixido N, Torrents O, Zabala M, Zuberer F, Cerrano C (2009) Mass mortality in northwestern Mediterranean rocky benthic communities: effects of the 2003 heat wave. Glob Chang Biol 15:1090-1103

Gaston KJ (2000) Global patterns in biodiversity. Nature 405:220-227

Graham EM, Baird AH, Connolly SR (2008) Survival dynamics of scleractinian coral larvae and implications for dispersal. Coral Reefs 27:529-539

Greenstein BJ, Pandolfi JM (2008) Escaping the heat: range shifts of reef coral taxa in coastal Western Australia. Glob Chang Biol 14:513-528

Harrison PL, Dalton SJ, Carroll AG (2011) Extensive coral bleaching on the world's southernmost coral reef at Lord Howe Island, Australia. Coral Reefs 30:775

Heyward AJ, Negri AP (2010) Plasticity of larval pre-competency in response to temperature: observations on multiple broadcast spawning coral species. Coral Reefs 29:631-636

Hobday AJ, Pecl GT (2013) Identification of global marine hotspots: sentinels for change and vanguards for adaptation action. Rev Fish Biol Fish 24:415-425

Hobday AJ, Alexander LV, Perkins SE, Smale DA, Straub SC, Oliver ECJ, Benthuysen JA, Burrows MT, Donat MG, Feng M, Holbrook NJ, Moore PJ, Scannell HA, Sen Gupta A, Wernberg T (2016) A hierarchical approach to defining marine heatwaves. Prog Oceanogr 141:227-238

Keith SA, Woolsey ES, Madin JS, Byrne M, Baird AH (2015) Differential establishment potential of species predicts a shift in coral assemblage structure across a biogeographic barrier. Ecography 38:1225-1234

Kersting DK, Bensoussan N, Linares C (2013) Long-term responses of the endemic reefbuilder Cladocora caespitosa to Mediterranean warming. PLoS One 8:e70820

Lafratta A, Fromont J, Speare P, Schönberg CHL (2016) Coral bleaching in turbid waters of north-western Australia. Mar Freshw Res 68:65-75

Last PR, White WT, Gledhill DC, Hobday AJ, Brown R, Edgar GJ, Pecl G (2011) Long-term shifts in abundance and distribution of a temperate fish fauna: a response to climate change and fishing practices. Glob Ecol Biogeog 20:58-72

Lough JM, Barnes DJ (2000) Environmental controls on growth of the massive coral Porites. J Exp Mar Bio Ecol 245:225-243

Markey KL, Abdo DA, Evans SN, Bosserelle C (2016) Keeping it local: dispersal limitations of coral larvae to the high latitude coral reefs of the Houtman Abrolhos Islands. PLoS One 11:e0147628

Mezaki T, Kubota S (2012) Changes of hermatypic coral community in coastal sea area of Kochi, high-latitude, Japan. Aquabiology 201:332-337

Miller MW, Hay ME (1996) Coral-seaweed-grazer-nutrient interactions on temperate reefs. Ecol Monogr 66:323-344 
Mizerek TL, Baird AH, Beaumont LJ, Madin JS (2016) Environmental tolerance governs the presence of reef corals at latitudes beyond reef growth. Glob Ecol Biogeog 25:979987

Moore JA, Bellchambers LM, Depczynski MR, Evans RD, Evans SN, Field SN, Friedman KJ, Gilmour JP, Holmes TH, Middlebrook R, Radford BT, Ridgway T, Shedrawi G, Taylor H, Thomson DP, Wilson SK (2012) Unprecedented mass bleaching and loss of coral across 12 degrees of latitude in Western Australia in 2010-11. PLoS One 7:e51807

Nakamura Y, Feary DA, Kanda M, Yamaoka K (2013) Tropical fishes dominate temperate reef fish communities within western Japan. PLoS One 8:e81107

Nozawa Y, Harrison PL (2000) Larval settlement patterns, dispersal potential, and the effect of temperature on settlement of larvae of the reef coral, Platygyra daedalea, from the Great Barrier Reef. Proc 9th Int Coral Reef Symp 1:409-416

Nozawa Y, Harrison PL (2007) Effects of elevated temperature on larval settlement and postsettlement survival in scleractinian corals, Acropora solitaryensis and Favites chinensis. Mar Biol 152:1181-1185

Pearce A, Feng M (2013) The rise and fall of the "marine heat wave" off Western Australia during the summer of 2010/2011. J Mar Syst 111-112:139-156

Pearce A, Lenanton R, Jackson G, Moore J, Feng M, Gaughan D (2011) The "marine heat wave" off Western Australia during the summer of 2010/11. Fisheries Research Report No. 222, Department of Fisheries, Perth, Western Australia, 40 pp

Perry AL, Low PJ, Ellis JR, Reynolds JD (2005) Climate change and distribution shifts in marine fishes. Science 308:1912-1915

Poloczanska ES, Brown CJ, Sydeman WJ, Kiessling W, Schoeman DS, Moore PJ, Brander K, Bruno JF, Buckley LB, Burrows MT, Duarte CM, Halpern BS, Holding J, Kappel CV, O’Connor MI, Pandolfi JM, Parmesan C, Schwing F, Thompson SA, Richardson AJ (2013) Global imprint of climate change on marine life. Nat Clim Chang 3:919925

Precht WF, Aronson RB (2004) Climate flickers and range shifts of reef corals. Front Ecol Environ 2:307-314

Randall CJ, Szmant AM (2009) Elevated temperature reduces survivorship and settlement of the larvae of the Caribbean scleractinian coral, Favia fragum (Esper). Coral Reefs 28:537-545

Richards Z, Kirkendale L, Moore G, Hosie A, Huisman J, Bryce M, Marsh L, Bryce C, Hara A, Wilson N, Morrison S, Gomez O, Ritchie J, Whisson C, Allen M, Betterridge L, Wood C, Morrison H, Salotti M, Hansen G, Slack-Smith S, Fromont J (2016) Marine biodiversity in temperate Western Australia: multi-taxon surveys of Minden and Roe Reefs. Diversity 8:7

Rodolfo-Metalpa R, Richard C, Allemand D, Ferrier-Pages C (2006) Growth and photosynthesis of two Mediterranean corals, Cladocora caespitosa and Oculina patagonica, under normal and elevated temperatures. J Exp Biol 209:4546-4556

Ross C, Ritson-Williams R, Olsen K, Paul VJ (2013) Short-term and latent post-settlement effects associated with elevated temperature and oxidative stress on larvae from the coral Porites astreoides. Coral Reefs 32:71-79 
Schiel DR, Foster MS (1986) The structure of subtidal algal stands in temperate waters. Oceanogr Mar Biol Annu Rev 24:265-307

Serrano E, Coma R, Ribes M (2012) A phase shift from macroalgal to coral dominance in the Mediterranean. Coral Reefs 31:1199

Serrano E, Coma R, Ribes M, Weitzmann B, Garcia M, Ballesteros E (2013) Rapid northward spread of a zooxanthellate coral enhanced by artificial structures and sea warming in the western Mediterranean. PLoS One 8:e52739

Smale DA, Wernberg T (2012) Ecological observations associated with an anomalous warming event at the Houtman Abrolhos Islands, Western Australia. Coral Reefs $31: 441$

Smale DA, Wernberg T (2013) Extreme climatic event drives range contraction of a habitatforming species. Proc R Soc Lond B Biol Sci 280:20122829

Sommer B, Harrison PL, Beger M, Pandolfi JM (2014) Trait-mediated environmental filtering drives assembly at biogeographic transition zones. Ecology 95:1000-1009

Steneck RS, Johnson CR (2013) Kelp forests: dynamic patterns, processes and feedbacks. In: Bertness MD, Bruno JF, Silliman BR, Stachowicz JJ(eds) Marine community ecology and conservation, Sinauer Associates, Sunderland, Massachusetts, pp 315-336

Sturges HA (1926) The choice of a class interval. J Am Stat Assoc 21:65-66

Thomson DP (2010) Range extension of the hard coral Goniopora norfolkensis (Veron \& Pichon 1982) to the south-east Indian Ocean. J R Soc West Aust 93:81-83

Thomson DP, Bearham D, Graham F, Eagle JV (2011) High latitude, deeper water coral bleaching at Rottnest Island, Western Australia. Coral Reefs 30:1107

Thomson DP, Babcock RC, Vanderklift MA, Symonds G, Gunson JR (2012) Evidence for persistent patch structure on temperate reefs and multiple hypotheses for their creation and maintenance. Estuar Coast Shelf Sci 96:105-113

Tittensor DP, Mora C, Jetz W, Lotze HK, Ricard D, Berghe EV, Worm B (2010) Global patterns and predictors of marine biodiversity across taxa. Nature 466:1098-1101

Vergés A, Tomas F, Cebrian E, Ballesteros E, Kizilkaya Z, Dendrinos P, Karamanlidis AA, Spiegel D, Sala E (2014a) Tropical rabbitfish and the deforestation of a warming temperate sea. J Ecol 102:1518-1527

Vergés A, Steinberg PD, Hay ME, Poore AG, Campbell AH, Ballesteros E, Heck KL Jr, Booth DJ, Coleman MA, Feary DA, Figueira W, Langlois T, Marzinelli EM, Mizerek T, Mumby PJ, Nakamura Y, Roughan M, van Sebille E, Gupta AS, Smale DA, Tomas F, Wernberg T, Wilson SK (2014b) The tropicalization of temperate marine ecosystems: climate-mediated changes in herbivory and community phase shifts. Proc R Soc Lond B Biol Sci 281:20140846

Veron JEN (1993) Corals of Australia and the Indo-Pacific. University of Hawaii Press, Honolulu

Veron JEN (2000) Corals of the world. Vol 1-3. Australian Institute of Marine Science, Townsville, Australia

Veron JEN, Marsh LM (1988) Hermatypic corals of Western Australia. Records and annotated species list. Supplement. Records of the Western Australian Museum. 29:1136 
Vieira C, Keshavmurthy S, Ju S-J, Hyeong K, Seo I, Kang C-K, Hong H-K, Chen CA, Choi K-S (2016) Population dynamics of a high-latitude coral Alveopora japonica Eguchi from Jeju Island, off the southern coast of Korea. Mar Freshw Res 67:594-604

Wernberg T, de Bettignies T, Bijo AJ, Finnegan P (2016a) Physiological responses of habitat-forming seaweeds to increasing temperatures. Limnol Oceanogr, 61:21802190

Wernberg T, Smale DA, Tuya F, Thomsen MS, Langlois TJ, de Bettignies T, Bennett S, Rousseaux CS (2013a) An extreme climatic event alters marine ecosystem structure in a global biodiversity hotspot. Nat Clim Chang 3:78-82

Wernberg T, Russell BD, Moore PJ, Ling SD, Smale DA, Campbell A, Coleman MA, Steinberg PD, Kendrick GA, Connell SD (2011) Impacts of climate change in a global hotspot for temperate marine biodiversity and ocean warming. J Exp Mar Bio Ecol 400:7-16

Wernberg T, Thomsen MS, Connell SD, Russell BD, Waters JM, Zuccarello GC, Kraft GT, Sanderson C, West JA, Gurgel CFD (2013b) The footprint of continental-scale ocean currents on the biogeography of seaweeds. PLoS One 8:e80168

Wernberg T, Bennett S, Babcock RC, de Bettignies T, Cure K, Depczynski M, Dufois F, Fromont J, Fulton CJ, Hovey RK, Harvey ES, Holmes TH, Kendrick GA, Radford B, Santana-Garcon J, Saunders BJ, Smale DA, Thomsen MS, Tuckett CA, Tuya F, Vanderklift MA, Wilson S (2016b) Climate-driven regime shift of a temperate marine ecosystem. Science 353:169-172

Yakovleva IM, Baird AH, Yamamoto HH, Bhagooli R, Nonaka M, Hidaka M (2009) Algal symbionts increase oxidative damage and death in coral larvae at high temperatures. Mar Ecol Prog Ser 378:105-112

Yamano H, Sugihara K, Nomura K (2011) Rapid poleward range expansion of tropical reef corals in response to rising sea surface temperatures. Geophys Res Lett 38:L04601

Yara Y, Oshima K, Yamanaka Y, Fujii M, Yamano H, Okada N (2011) Projection and uncertainty of the poleward range expansion of coral habitats in response to sea surface temperature warming: A multiple climate model study. Galaxea 13:11-20

\section{Figures}




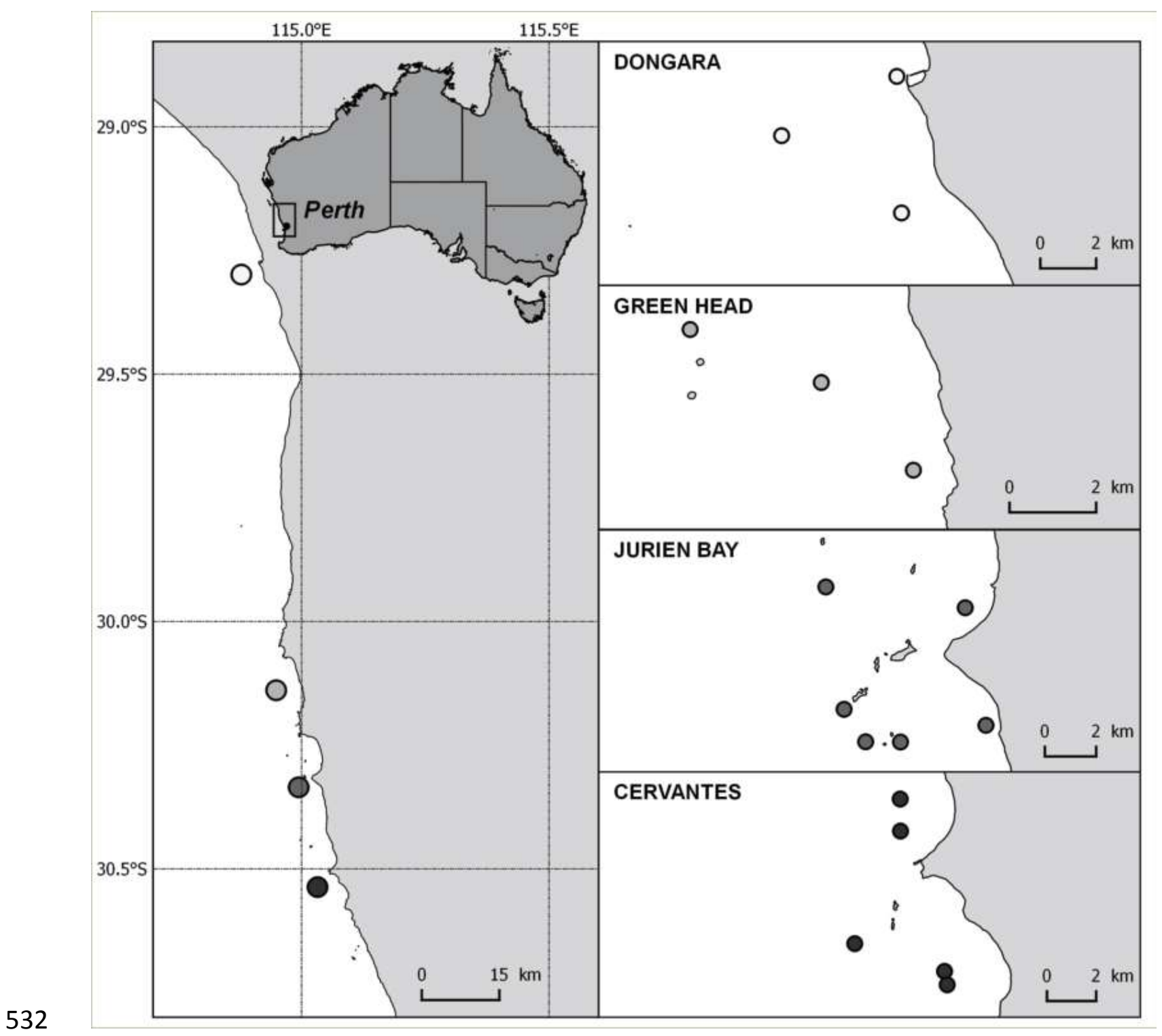

533 Fig. 1 Sample regions and sites within the mid-west of Western Australia. The grey scale for

534 the dots on the left panel match the four regions (Dongara, Green Head, Jurien Bay and

535 Cervantes) on the right panels 


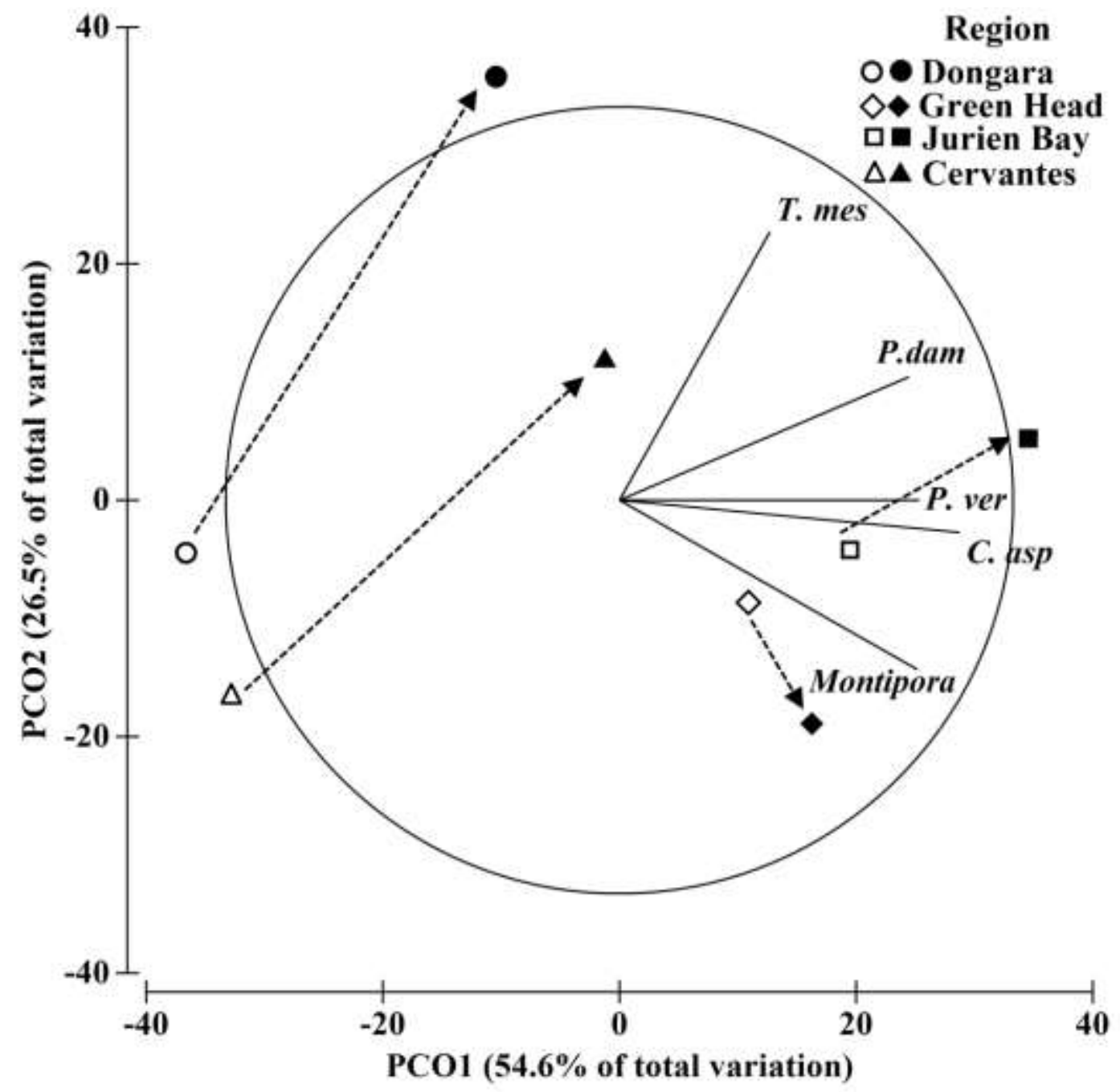

536

537 Fig. 2 Principal coordinates analysis of variation in coral community structure on mid-west

538 temperate reefs. The first two axes (PCO1 and PCO2) explain $81.1 \%$ of the variability in

539 multivariate space. White shapes denote before heatwave centroids and black shapes are

540 centroids for after the heatwaves. $T$. mes $=$ Turbinaria mesenterina, $P$. dam $=$ Pocillopora

541 damicornis, $P$. ver $=$ Plesiastrea versipora, C. asp $=$ Coelastrea aspera 


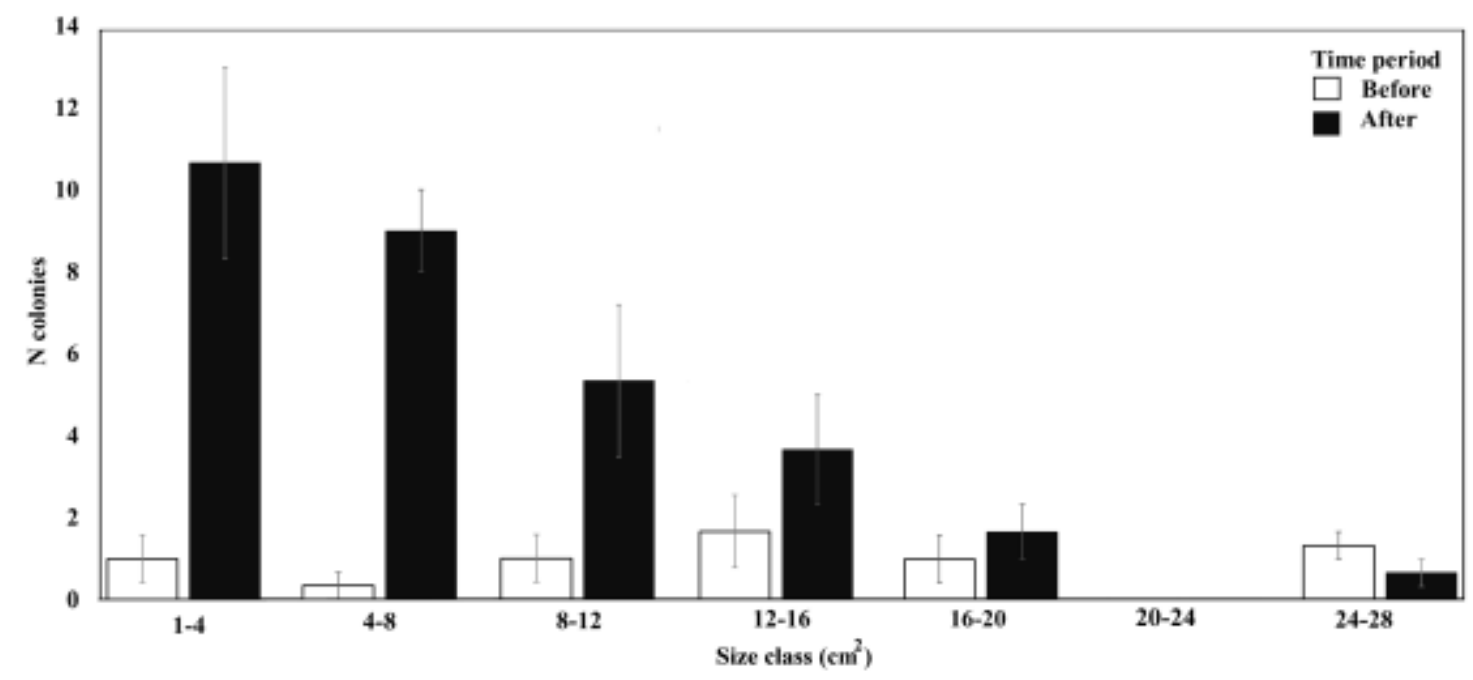

543

544 Fig. 3 Size-class distributions of Plesiastrea versipora in the mid-west regions before

545 multiple heatwaves (2005/2006) and after the heatwaves (2013). Graphs are based on pooled

546 data for the mid-west (excluding Dongara) and estimates of coral area, assuming corals are

547 elliptical

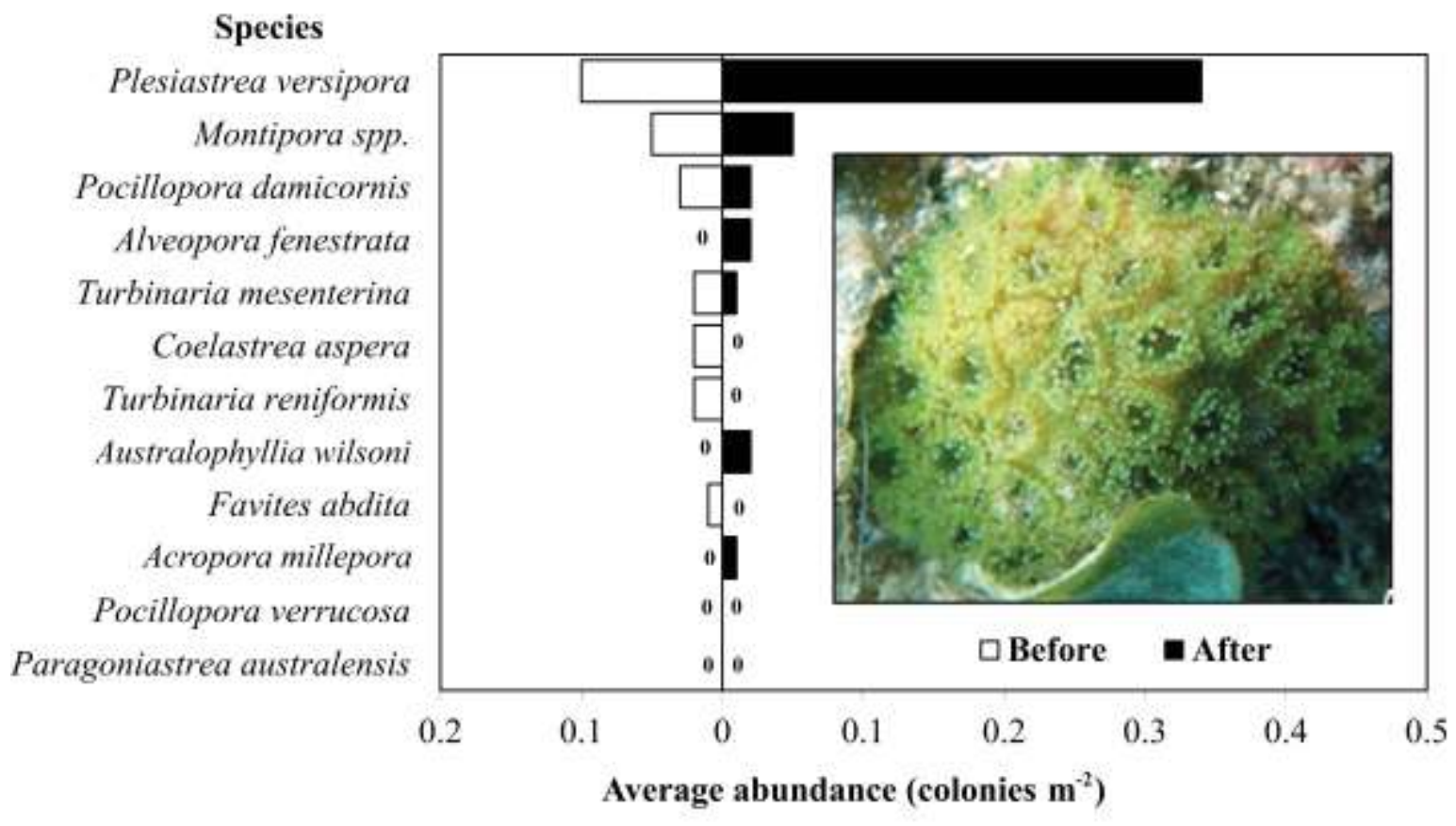


549 Fig. 4 SIMPER analysis showing the change in the average abundance of the 12 species

550 recorded before and after heatwaves. Inset photo shows a small Plesiastrea versipora colony.

551 Photo: C. Tuckett

552
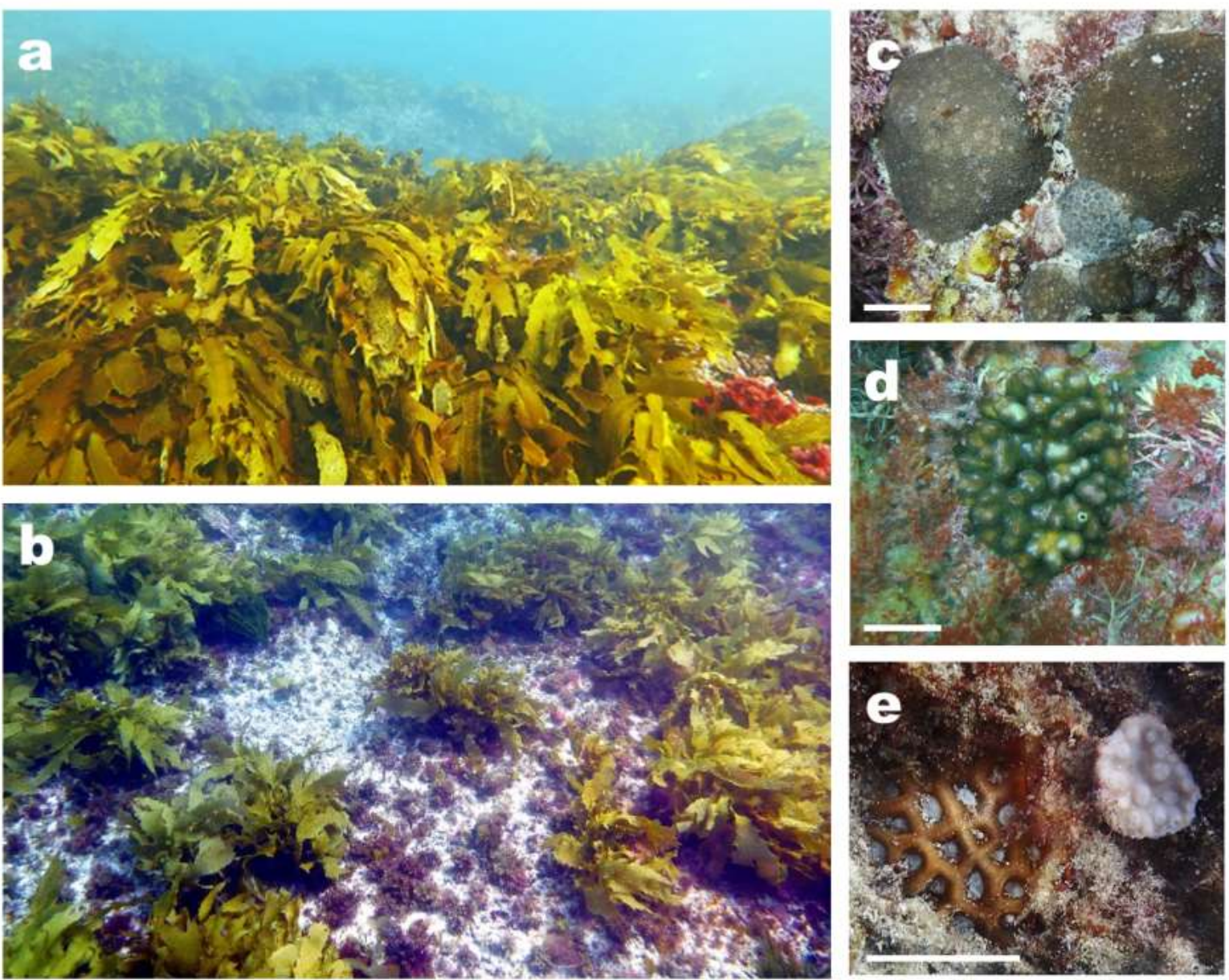

553

554 Fig. 5 Underwater photographs from mid-west Western Australia showing a benthos

555 dominated by the seaweed canopy prior to the marine heatwaves; $\mathbf{b}$ benthos with significantly

556 reduced canopy and large open patches post heatwaves; $\mathbf{c}$ juvenile Plesiastrea versipora

557 colonies found post heatwaves; d juvenile Pocillopora damicornis colony found post 
558 heatwaves; e juvenile Merulinidae and Turbinaria post heatwaves. $\mathbf{c}-\mathbf{e}$ Scale bars $=2.5 \mathrm{~cm}$.

559 Photo credits: a, b T. Wernberg; c, d T. de Bettignies; e C. Tuckett

560

561 Table 1. Comparison of coral communities before (2005-2006) and after (2013) multiple

562 heatwaves in the midwest of Western Australia.

Data Summary

Time Total colony count

Small colony count

Large colony count

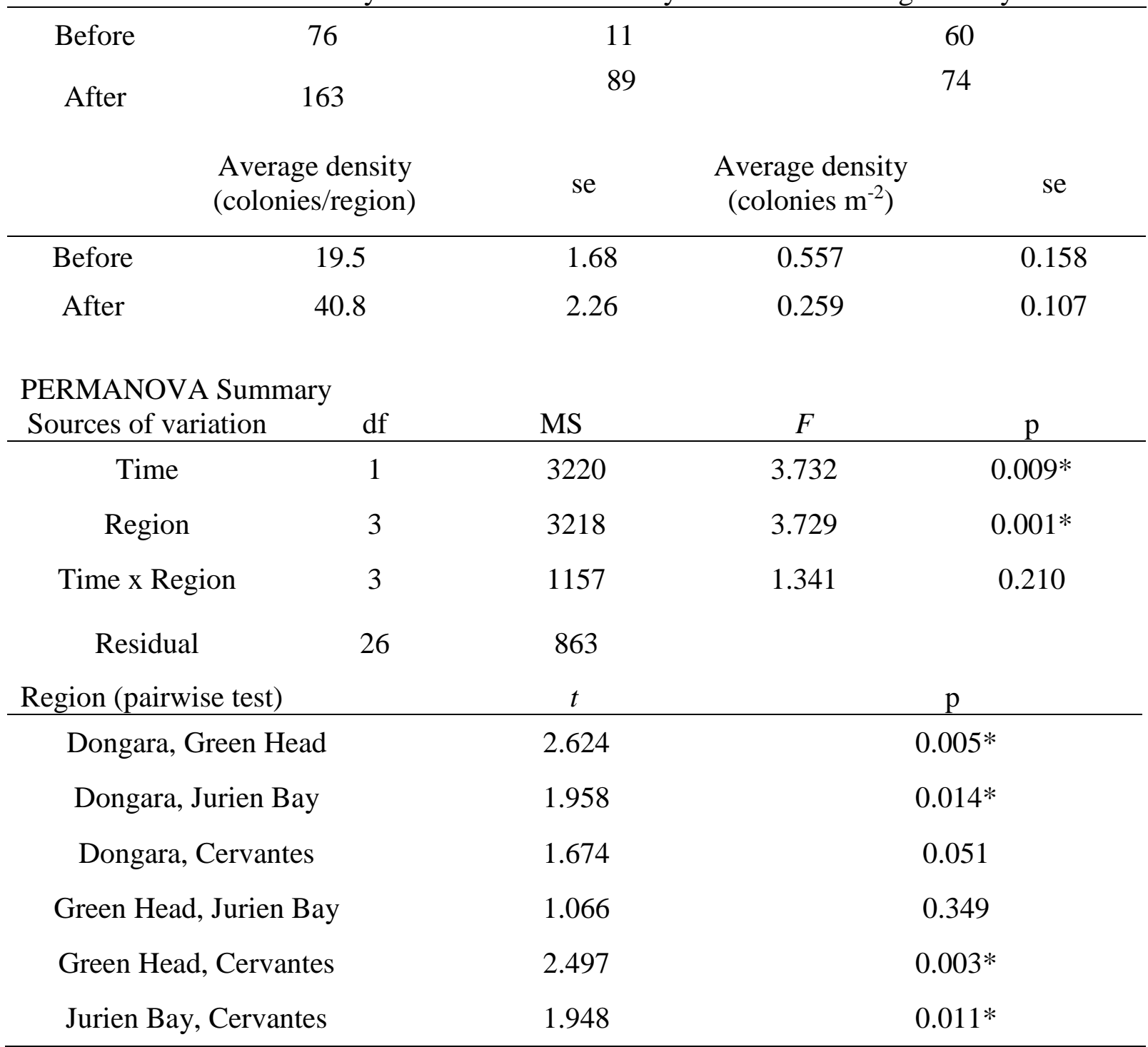

*significant difference $<0.05$

564 Total colony counts are for all regions $(\mathrm{n}=4)$, small colonies are $<12 \mathrm{~cm}^{2}$, large colonies $>12 \mathrm{~cm}^{2}$, mean colony density is given per region and per $\mathrm{m}^{-2}$. Small and large colony counts do not equal the total for 'before' as five colonies were not measured. Permutational analysis of variance (PERMANOVA) tested for differences in 
567 community structure between years (fixed) and regions (fixed). PERMANOVA is based on a zero adjusted Bray

568 Curtis similarity matrix. Pairwise testing showing the variability between regions. 